\title{
Testicular Descent
}

\author{
Charalampos Mamoulakis, ${ }^{1}$ Spyridon Antypas, ${ }^{2}$ Frank Sofras, ${ }^{1}$ \\ Atsushi Takenaka, ${ }^{3}$ Nikolaos Sofikitis ${ }^{4}$
}

${ }^{1}$ Department of Urology, University General Hospital of Heraklion, University of Crete Medical School, Heraklion, Crete, Greece; ${ }^{2}$ First Pediatric Surgery Clinic, Aghia Sophia Children's Hospital, Athens, Greece; ${ }^{3}$ Department of Urology, Tottori University School of Medicine, Yonago, Japan; ${ }^{4}$ Laboratory of Molecular Urology and Genetics of Human Reproduction, Department of Urology, Ioannina University School of Medicine, loannina, Greece

\section{INTRODUCTION}

Normal testicular descent (TD) is known to be a complex, multistage process involving the interplay of different anatomical structures, hormones, environmental and genetic factors, but its purpose and the exact etiology of TD impairment remain largely unknown. ${ }^{1}$ TD is under hormonal control and hypothalamo-pituitary-gonadal axis integrity is usually a prerequisite for normal TD; however, hormonal deficiencies do not appear to be common causes of TD impairment. ${ }^{2}$ Several animal and human studies are underway to test the hypothesis that in utero factors, including environmental and maternal lifestyle factors, may interfere with normal TD. ${ }^{3}$ Genetic factors are also thought to cause TD impairment under certain conditions by gene-environment interactions and the overall evidence supports a genetic basis, at least in some cases. ${ }^{1,4,5}$ The role of several genetic factors, including Insulin-like 3 (INSL3) gene alterations, has

Key words: Cryptorchidism, Human, Mammal, Testis, Undescended testis

Address for correspondence:

Charalampos Mamoulakis, Department of Urology,

University General Hospital of Heraklion, Voutes-Stavrakia,

71110 Heraklion, Crete, Greece; Tel.: +30 2810392340 ,

Fax: +30 2810 542066, E-mail: c.mamoulakis@med.uoc.gr

Received: 05-04-2015, Accepted: 21-08-2015 recently been evaluated in a large study conducted at our institutions. ${ }^{6-8}$ In line with other studies, it was concluded that known genetic factors are responsible for only a small proportion of TD impairment ${ }^{3}$ and that novel candidate factors should be sought. ${ }^{6-8}$ The aim of the present review is to summarize current knowledge on normal TD in the human, including evolutionary aspects and interspecies differences.

\section{TD AND SCROTAL DEVELOPMENT AMONG MAMMALIAN SPECIES: EVOLUTIONARY IMPLICATIONS}

TD occurs exclusively in mammals (Theria). ${ }^{9}$ However, the degree of TD varies highly and abdominal testes are found in a large number of taxa. Furthermore, genera within mammalian families often exhibit variations in testicular position. ${ }^{10-12}$ Six mammalian orders contain species with internal testes and species with external testes (Marsupialia: kangaroo, etc.; Chiroptera: bats; Rodentia: rats, mice, porcupines, prairie dog, chinchilla, etc.; Carnivora; Perissodactyla (odd-toed ungulates): horses, rhinos, etc.; and Artiodactyla (even-toed ungulates): pigs, hippos, camels, deer, cows, etc.). ${ }^{12}$ Mammalian testes position can be generally classified as transabdominal and inguinoscrotal. Each category is further divided into three groups, resulting in a total of six distinct testicular positions: 1) embryonic (no descent from embryonic position); 2) intermediate (partially descended, intra-abdominal position; 3) internal inguinal position; 
4) emergent position (some part protrudes through the inguinal ring); 5) beyond the inguinal ring but not within a true scrotum position, and 6) scrotal position (within a true scrotum). ${ }^{10} \mathrm{TD}$ is developmentally, physiologically and evolutionarily a costly process. ${ }^{13}$ Therefore, benefits must be great to outweigh costs. Several hypotheses have been developed to explain TD and scrotal evolution, the most popular of which are: a) the hypothesis of temperature dependency of spermatogenesis $;{ }^{14} b$ ) the mutation rates hypothesis $;{ }^{15}$ c) the display hypothesis; ${ }^{16}$ d) the cold storage hypothesis $;{ }^{17}$ and e) the training hypothesis. ${ }^{18,}$

The oldest and best established hypothesis is that of temperature dependency of spermatogenesis originated by Moore, ${ }^{14}$ according to which testes descend into the scrotum because a low-temperature environment is necessary for viable sperm production. Normal spermatogenesis and epididymal storage in many mammalian species require lower than core body temperatures. ${ }^{10,19-22}$ Abdominal temperatures $\left(35-38^{\circ} \mathrm{C}\right)$ can hamper spermatogenesis, ${ }^{20-21}$ and also have a detrimental effect upon long-term spermatozoa storage in the epididymis. ${ }^{17}$ Consequently, most mammals, including humans, have acquired sophisticated anatomical/physiological adaptations, ${ }^{9}$ to keep their testes cool $\left(\sim 3-5^{\circ} \mathrm{C}\right.$ below core body temperature). This hypothesis has been criticized merely based on the fact that ascrotal mammalian species can still maintain successful sperm production. ${ }^{10,17}$ However, accumulated data show that the vast majority of these species eventually do not have higher testicular temperatures compared to scrotal species. Thus, many ascrotal taxa like seals ${ }^{23}$ and Catacea $^{24}$ have developed specific mechanisms for cooling their testis (e.g. venous plexuses carrying cool blood to the spermatic arteries), whereas others such as Monotremata ${ }^{25}$ need no such mechanisms due to their low core body temperatures. The Hyracoidea and Proboscidea represent an exception as they lack a specific internal thermoregulation mechanism. ${ }^{26}$ Nevertheless, hyraxes can control body temperature using behavioral means, ${ }^{25}$ whereas elephants are regarded as "immune" to high temperature effects on sperm viability. ${ }^{26}$

A modification of the above hypothesis (the mutation rates hypothesis) was proposed by Short ${ }^{15}$ according to which the purpose of the evolution of the scrotum and TD was to keep the mutation rate in the male germline under control rather than to ensure normal spermatogenesis. In humans, mutation rates are lower among males than females. ${ }^{27,28}$ This, combined with the fact that elevated temperatures are associated with increased mutation rates, suggests that cooling the testes helps to keep mutation rates at acceptable levels. ${ }^{20,29}$

The "display" hypothesis suggested by Portman ${ }^{16}$ is based on the assumption that testes descend to a visible position (scrotum) because of their importance in social competition, either as an avantage in female choice of mates or as a signal of dominance in the competition among males. In some taxa, the scrotum is brightly or distinctively colored attracting female attention to the sexual organs. This is the case in primates for example, where the presence of pigmented scrota is associated with breeding systems characterized by intense male-male competition. Although a number of observations are consistent with this hypothesis, its failure to explain the variable location of the testes among ascrotal species combined with the fact that pigmented scrota are not always readily presented (nocturnal animals, furred pigmented scrota) weakens its explanatory power. It is more possible that the scrotum initially evolved for another function and was subsequently retained and coopted as a signaling device by some species (most notably primates) due to their particular sexual behavior systems. ${ }^{11}$

The "cold storage" hypothesis was originated by Bedford. ${ }^{17}$ According to this hypothesis, TD into the scrotum (whose primary function is to store sperm in a cool environment) is a secondary phenomenon, subsequent to the epididymal descent (evolutionarily "primary mover" in scrotal evolution). It was pointed out that the sperm storage organ in mammals (usually the epididymis) always precedes $\mathrm{TD}$, descending to the body wall or to a scrotal-like out-pocketing in most species with abdominal testes. ${ }^{17,30}$ However, the main flaw of this hypothesis is the fact that in some ascrotal taxa, the epididymis lies subcutaneously or intra-abdominally (e.g. hyraxes, elephant shrew ${ }^{31}$ ).

The "training" hypothesis was formulated by Zahavi ${ }^{18}$ and represents a radically different point of view since it considers the scrotum as a purposely 
hostile environment for sperm rather than an optimized one. The main idea is that TD into the scrotum occurs because spermatozoa must be "trained" for the physiologically rigorous female environment. The physiological basis is that the blood supply to scrotal testes is remarkably poor mainly due to low blood pressure within the testicular arteries. In scrotal mammals these arteries are exceedingly long and convoluted with a very small diameter compared to ascrotal ones that possess straight and short testicular arteries. ${ }^{32} \mathrm{In}$ addition, higher affinity of hemoglobin for oxygen at below body core (scrotal) temperatures ${ }^{33}$ impairs the appropriate supply of oxygen in the testicular tissue. The response to lower oxygen supply is an increase in size, number and efficiency of mitochondria of the maturing spermatocyte in a way similar to that observed in striated muscle cells during anaerobic training, a modification that enables spermatozoa to perform better during active transport in the female reproductive tract (better swimming and/or longer survival of spermatozoa). ${ }^{34}$ The main strength of this hypothesis is that it may explain the entire range of variation in testicular position among mammalian species: scrotal testes produce fewer sperm of higher quality, while ascrotal testes produce more sperm of lower quality. Zahavi's hypothesis has been criticized mainly on the basis that testicular blood supply might have been modified with more simple mechanisms compared to the evolution of a complicated system such as scrotal development.

\section{PHYSIOLOGY OF TD IN THE HUMAN}

John Hunter published the first important, highly accurate description of TD in humans. In 1786, he described the fetal testis and epididymis in the abdomen and he introduced the term "gubernaculum" (derived from the Latin word meaning helm or rudder) for the caudal ligament of the testis, which he believed to be responsible for steering the testis into the scrotum. ${ }^{35}$ Since Hunter's first description, the gubernaculum has been described by many authors and numerous theories have been proposed to explain the cause and mechanism of TD. ${ }^{36}$ Although it is not globally accepted that the gubernaculum holds an essential role in TD, the fact that it represents a structure unique to the male fetus offers a convincing explanation for why the fetal testis descends in contrast to the ovary. Furthermore, ascrotal animals i.e. reptiles and primary testiconda, such as monotremata, hyraxes and elephants, show either no sign of a gubernaculum at any stage of their development or partial gubernacular development (e.g. Hyrax). On the other hand, secondary testiconda (such as Catacea) present gubernacular primordia already from the onset of their sexual differentiation, which develop further into large masses of dense connective tissue, a finding that supports the notion that the testes of Catacea, in evolutionary terms, had once been scrotal [Catacea are considered descendants of terrestrial mammals (ungulates) with TD].

However, despite extensive work on TD, the matter remains controversial since no unified theory explaining the causes/mechanisms of TD exists as yet. This is probably due to the incorrect/incomplete observations many of the existing theories are based on, the kind of material used (e.g. histo-anatomical studies on autopsy material cannot determine the forces responsible for TD) and mainly the indiscriminate extrapolation of findings in specific animal models among different spiecies. In fact, there is no ideal animal model to study TD due to marked morphological differences among the structures involved. Although it has long been noted that TD should be primarily studied in humans to avoid false analogies drawn from animals, ${ }^{37}$ limitations of research on fetal processes in human or even in large mammals (better models for studying TD) account for the ample use of Glires (especially Rodentia: e.g. rats, mice but also Lagomorpha: e.g. rabbits).

\section{Embryology of TD}

It was first proposed that TD is a multistage procedure by Gier and Marion in 1969. ${ }^{38}$ Later, a biphasic model with two morphologically and hormonally distinct phases was suggested to explain TD in normal human males by Hutson. ${ }^{39}$ According to this model, the $1^{\text {st }}$ (transabdominal) phase of TD (TTD) occurs by the $8^{\text {th }}$ gestational week $(\mathrm{GW})$, comprising the relative testis movement from its initial posterior abdominal position adjacent to the kidney to the internal inguinal ring and is controlled by a non-androgenic hormone/ factor (possibly Mullerian inhibiting substance, MIS). The $2^{\text {nd }}$ (inguinoscrotal) phase of TD (ISTD) begins at the $26^{\text {th }} \mathrm{GW}$ and consists of the androgen-dependent 
descent of the testis from the internal inguinal ring to the scrotum. ${ }^{40,41}$ Between the $26^{\text {th }}-28^{\text {th }} \mathrm{GW}$, the testis descends rapidly via the inguinal canal, to move slowly thereafter towards the scrotum, reaching it at the $35^{\text {th }}-40^{\text {th }} \mathrm{GW} \cdot{ }^{40}$ In the human, migration of the gubernaculum and the testis occur simultaneously, whereas in rodents gubernacular migration precedes $\mathrm{TD}^{42}$

Between the $10^{\text {th }}-15^{\text {th }} \mathrm{GW}$, during TTD, the cranial suspensory ligament (CSL) that holds the urogenital tract near the developing diaphragm regresses, while simultaneously $\left(8^{\text {th }}-15^{\text {th }} \mathrm{GW}\right)$ the gubernaculum that has already appeared by the $7^{\text {th }} \mathrm{GW}$ enlarges caudally and forms the gubernacular bulb. ${ }^{43}$ Gubernacular caudal enlargement keeps the testis anchored close to the future inguinal region via traction applied through the gubernacular cord, which shortens as it becomes incorporated into the bulb. ${ }^{44,45}$ The net effect is testis tethering near the groin and enablement of future TD, while the kidney migrates cranially during enlargement of the abdominal cavity. ${ }^{46}$

ISTD requires a) development of the processus vaginalis, $b$ ) prior dilation of the inguinal canal by the bulb and c) some abdominal pressure to force the testis downwards through the canal. The processus vaginalis is a peritoneal herniation which develops as the anterior aspect of the gubernaculum elongates caudally ${ }^{43,47}$ Eventually, the development of the inguinal canal starts as the processus vaginalis enters the caudal abdominal wall forming an envagination which represents the internal inguinal ring during the $8^{\text {th }} \mathrm{GW}$. The formation of the processus vaginalis takes place within the gubernaculum to form an annular cavity dividing the latter into a central mesenchymal column and an outer parietal layer. After TD has been completed, the central gubernacular column regresses, leaving behind a fibrous testo-scrotal attachment. ${ }^{9}$ The cremaster muscle develops within the outer parietal layer of the gubernaculum, forming a strip of muscle ${ }^{48}$ which is attached to the inguinal abdominal wall. The gubernaculum is innervated by the genital branch of the genitofemoral nerve (GFN) ${ }^{49}$ The distal gubernacular end in humans is free with no firm scrotal attachment, ${ }^{40,50}$ strong evidence against the concept that the testis is "pulled" by the gubernaculum down to the scrotum. ${ }^{40,41}$ The force probably derives from the inta-abdominal pressure (Gier and Marion,
$1969)^{42,51,52}$ transmitted directly or indirectly to the testis via the lumen of the processus vaginalis and the gubernacular cord, respectively. ${ }^{53}$

\section{Transabdominal phase of TD}

\section{Regression of the CSL under the influence of androgens}

The CSL is a muscular structure derived from the mesonephric mesenchyme with a cord-like appearance, which borders the mesonephric mesentery cranially, attaching the ovary and genital duct to the craniolateral surface of the dorsal abdominal wall, near the ventral aspect of the last rib. The primordium of the CSL is present in both sexes and prevention of the fetal CSL outgrowth is an androgen-dependent process. ${ }^{54-56}$ Males prenatally exposed to antiandrogens show CSL development in a female-like fashion, while prenatal exposure of females to androgens prevents CSL development. ${ }^{56,57}$ Similarily, patients with complete or partial androgen insensitivity syndrome (CAIS/ PAIS) preserve the CSL. ${ }^{58,59}$

Whether or not CSL regression is the key factor in TD is disputed. CSL regression is probably a prerequisite for TD. ${ }^{60}$ However, it has been shown that CSL regression alone is insufficient to cause gonadal descent (46XX individuals exposed prenatally to androgens retained ovaries in a normal position) ${ }^{6}{ }^{6}$ TTD does not seem to be interrupted in cases with CSL retention in testicular feminization (Tfm) in mice (testes descended at the internal inguinal ring) nor in patients with CAIS/PAIS (testes descended at the internal inguinal ring or beyond).$^{59}$ However, bilateral intra-abdominal testes associated with a bilaterally retained CSL have been described in the dog. ${ }^{54}$ Furthermore, the CSL is retained in testicular feminization in rats, which exhibit intra-abdominal, inguinal and scrotal testes at $20 \%, 67 \%$ and $13 \%$, respectively, suggesting that CSL retention possibly has a role in TTD of the rat. ${ }^{56}$ Nevertheless, it is generally agreed that the role of the CSL in TD is limited in at least some species. ${ }^{53,56,62}$

\section{The "gubernacular swelling reaction"}

Caudal enlargement of the gubernaculum during TTD is known as the "gubernacular swelling reaction" (GSR). ${ }^{43}$ GSR is caused by rapid cell proliferation and deposition of significant amounts of extracellular 
matrix consisting mainly of hydrophilic molecules (glycosaminoglycans and hyaluronic acid). These molecules are probably responsible for the increase in water within the matrix that makes the end of the gubernaculum bulky and gelatinous similar to the Wharton's jelly found in the umbilical cord..$^{40,63-65}$ GSR has been closely linked to TTD. ${ }^{44}$ Development of a male-like gubernaculum and partial ovarian descent in a) bovine freemartin (a female fetus exposed to hormonal influence of the testes from male twins due to fusion of chorionic blood circulations soon after implantation ${ }^{66,67}$ and b) in female rabbit fetuses that received fetal testis graft ${ }^{68}$ demonstrated participation of a fetal testicular factor in gubernacular development/TD. The testicular hormone/factor promoting TTD via gubernacular outgrowth remained unknown for decades, receiving names such as "factor $\mathrm{X}$ " ${ }^{69}$ and "third hormone". ${ }^{67}$

\section{Evidence against androgenic control of TTD}

There is strong evidence that GSR/TTD is not under androgenic control in a great number of mammalian species. AR-positive cells were identified in the gubernacular mesenchymal core both in rats $^{70,71}$ and pigs. ${ }^{72}$ However, in the rat, gubernacular AR decrease dramatically from fetal to postnatal development ${ }^{70}$ showing maximal expression between $18-21 \mathrm{pcd},{ }^{71}$ namely after the completion of GSR in this species. On the other hand, AR receptor binding affinity in the gubernaculums of the pig is lower than in other known androgen-sensitive target tissues such as the prostate. ${ }^{72}$ Clinical examples supporting this theory include patients with CAIS/PAIS who have bilateral TD impairmnet. In the majority of cases, testes are palpable bilaterally in the labioscrotal folds or inguinal regions of such patients..$^{59}$ In addition, there is a great number of experimental studies supporting this hypothesis. In the fetal pig, raccoon, dog and mouse with testicular feminization syndrome, GSR/ TTD remains normal. ${ }^{74,75}$ Furthermore, GSR/TTD is not impaired after exposure of monkeys, rats, mice and rabbits prenatally or dogs postnatally to cyproterone ${ }^{76-78}$ or rats prenatally to flutamide. ${ }^{79}$ In addition, androgens injected into rat or pig fail to stimulate GSR in female fetuses ${ }^{44}$ while androgen replacemet after orchidectomy does not prevent gubernacular atrophy in the fetal dog. ${ }^{80,81}$ However, in vitro studies of an- drogen impact upon gubernacular cell proliferation yielded inconsistent results. ${ }^{82-85}$ This is probably due to anatomical/structural differences of gubernaculae among species (e.g. the porcine gubernaculum consists exclusively of mesenchymal cells, in contrast to the gubernaculum of the rat that possesses a muscular outer layer, an anatomical equivalent of the porcine cremaster muscle).

\section{Evidence against a significant role of MIS in TTD}

According to Hutson's biphasic model, the nonandrogenic hormone that regulates GSR/TTD is possibly MIS. ${ }^{39}$ The concept is based on experiments showing that exogenous estrogens in the fetal mouse cause Mullerian ducts retention, ${ }^{86}$ GSR inhibition ${ }^{87,88}$ and complete TTD blockage, ${ }^{89}$ which is not reversed by simultaneous exogenous exposure to androgens..$^{90}$ These results led to the hypothesis that estrogens have a primary effect of inhibiting Mullerian duct regression and a second primary effect of inhibiting GSR/ TTD, not by suppressing androgen secretion as it had been postulated previously ${ }^{45}$ but via suppression of a possible MIS effect on the gubernaculum. ${ }^{89-91}$ MIS was further investigated because in patients with persistent Mullerian duct syndrome (PMDS), both testes are located in the ovarian position in $\sim 60-70 \%$ of cases ${ }^{92}$ and the gubernaculum is feminine-like, i.e. thin and elongated. ${ }^{93}$

However, there is strong evidence against a significant role of MIS in GSR/TTD. Normal TD occurs in fetal rabbits immunized against bovine MIS despite complete or partial retention of the Mullerian ducts. ${ }^{94}$ In addition, semipurified bovine MIS failed to induce in vitro DNA synthesis and cell division of cultured fibroblasts from the fetal porcine gubernaculum, ${ }^{83}$ while MIS appears to have minimal proliferative action on rat gubernacular cells in vitro due to a weak expression of MIS II receptors ${ }^{84}$ Furthermore, mice homozygous for targeted mutations in the MIS/MIS II receptor genes present with normally descended testes and normal GSR, while ovarian descent is not observed in transgenic femal mice overexpressing MIS. ${ }^{95-97}$ However, male homozygous Tfm/MIS double mutant mice are pseudohermaphrodite with severely impaired TTD, although the Tfm and MIS mutants taken individually do not demonstrate impaired TTD. ${ }^{96}$ 
This fact might imply that there is an as yet unknown mechanism via which androgen may regulate MIS activity in the gubernaculum, or vice versa, to govern TTD. ${ }^{98} \mathrm{~A}$ further argument against the proposed MIS role in GSR/TTD is that persistence of Mullerian ducts is rarely seen in patients with inta-abdominal testes, ${ }^{86}$ while the intra-abdominal testicular location in PMDS has been suggested as being due to a testicular anatomic connection with the Mullerian ducts (anatomic blockade of TD by the persistent ducts $^{62}$ rather than due to the absence of GSR. ${ }^{59,99,100}$

\section{The role of INSL3 in TTD}

In an in vitro study on the proliferation of fetal pig gubernacular cells, ${ }^{83}$ it was found that the extract from fetal porcine testis during TTD contained a low molecular weight $(<3.5 \mathrm{kD})$ fraction to which gubernacular cells responded. It was suggested that this bioactive fraction probably contained the factor(s) promoting TD. A number of known polypeptide growth factors (epidermal growth factor, insulin, fibroblast growth factor, platelet-derived growth factor and TGF $\beta$ ) and the testicular hormones tested (androgens, MIS, inhibin) showed only subtle stimulatory activity on gubernacular cells and were therefore excluded as putative TTD regulators. The above unknown factor received the name "descendin" and later it was proposed that it is a novel hormonal peptide secreted by fetal testicular cells, which was named "gubernaculotropin". ${ }^{85}$ Based on gene knock-out mice studies, ${ }^{101,102}$ a hormone with "descendin"/"gubernaculotropin"-like activity was detected and named "Insl3". The Insl3 gene product, also known as Leydig cell insuline-like hormone or relaxin-like factor, is a member of the insulin peptide hormone superfamily ${ }^{103,104}$ and is composed of an $\mathrm{A}$ and a B chain connected by a C-peptide that is cleaved during the active peptide maturation. ${ }^{103}$

The Insl3 gene is maximally expressed in both fetal and mature adult-type Leydig cells, whereas it is only weakly expressed in prepubertal immature Leydig cells and the ovary (with an exception being the ruminant ovary that exhibits a very high degree of expression). ${ }^{104,105}$ Ins13 transcripts are found in the developing testis of all mammalian species ${ }^{106}$ but not in the gubernacular bulb or in other neighboring tissues. ${ }^{101}$ They are first detected at $13.5 \mathrm{pcd}$ in Leydig cells (exclusive source in the testis) ${ }^{105}$ and remain constant through the $3^{\text {rd }}$ postnatal week when increases are observed coincident with the first wave of spermatogenesis/germ cell maturation reaching their highest level in the adult testis. ${ }^{106}$ In contrast, in females, transcripts are first detected at post-natal day 6 in theca cells of small antral follicles (expression is correlated with the selection of follicles to become preovulatory and in a lesser degree in the luteal ovarian cells. ${ }^{107}$

It was shown that Ins13 ${ }^{-/}$male mice are viable but sterile, exhibiting bilateral intra-abdominal testes due to gubernacular developmental abnormalities, resembling the structure of the wild type females, which is characterized by the appearance of a flat thin bulb, elongated cord, absence of normal structural organization into outer (myoblasts)-inner (mesenchymal) layers and presence of some muscular development but absence of the mesenchymal core. ${ }^{101,102,108}$ Apart from the gubernacular structure/ testicular position, the rest of the genital tract, CSL regression, sexual behavior and serum testosterone levels appear normal. These results indicate that Ins13 stimulates outgrowth/differentiation of gubernacular primordium in an androgen-independent way in male mice, while androgen-mediated CSL regression is Insl3-independent. ${ }^{101,102}$

In vitro studies of an Insl3 and androgens effect upon rat gubernacular proliferation activity suggest that both are required for induction of gubernacular development/differentiation. ${ }^{82,86}$ However, there is strong evidence that in vivo Insl3-mediated activity upon the gubernaculum is androgen-independent. ${ }^{109-110}$ This is supported by transgenic mice results with overexpressing active Insl3 in the pancreas during prenatal and postnatal development of female and male Insl3 $3^{--}$mice. Expression of the transgenic allele in Insl3-deficient mice remedies TD descent in male mutants. On the other hand, all transgenic females display bilateral inguinal hernias/descended ovaries over the bladder (attached to the abdominal wall via the well-developed CSL and the gubernaculum) due to Insl3-induced gubernacular development. Administration of dehydrotestosterone during prenatal development suppresses formation of the CSL allowing the ovaries to further descend into the processus vaginalis. 
A critical aspect concerning INSL3 function and underlying molecular mechanisms governing human gubernacular differentiation is the identification of a corresponding receptor. INSL3 appears to govern TTD by controlling differentiation of the gubernaculum, an action mediated by the leucine-rich repeat-containing G-protein-coupled receptor 8 (LGR8). ${ }^{111}$ It has been shown that INSL3 activates LGR8 receptors through the adenylate cyclase pathway in the gubernaculum, leading to gubernacular cell proliferation. ${ }^{111}$ The INSL3-LGR8 system also appears to play a role in fertility via a paracrine action in the testis, that is, INSL3 biosynthesis by Leydig cells stimulates LGR8 expressed in meiotic spermatogenic cells to suppress germ cell apoptosis. ${ }^{112}$
The human INSL3 gene maps to chromosome 19p13.2-p12 consisting of two exons: exon 1 encodes for a signal peptide (present in the preproprotein), the $\mathrm{B}$ chain and the first eight aminoacids of the $\mathrm{C}$ peptide; exon 2 encodes for the rest of the $\mathrm{C}$-peptide and the A chain. ${ }^{113}$ Insl3 appears to be necessary for the development of the gubernacular mesenchymal component (the predominat muco-polysacharide structure in the human, dog and pig gubernaculum). In contrast, the gubernaculum of rodents is mainly composed of cremasteric muscle with a mesenchymal core. However, Insl3 does not seem to play a significant role in the development of the cremaster, the thickness of which appears to be both MIS- and estrogen-dependent. ${ }^{95,114}$

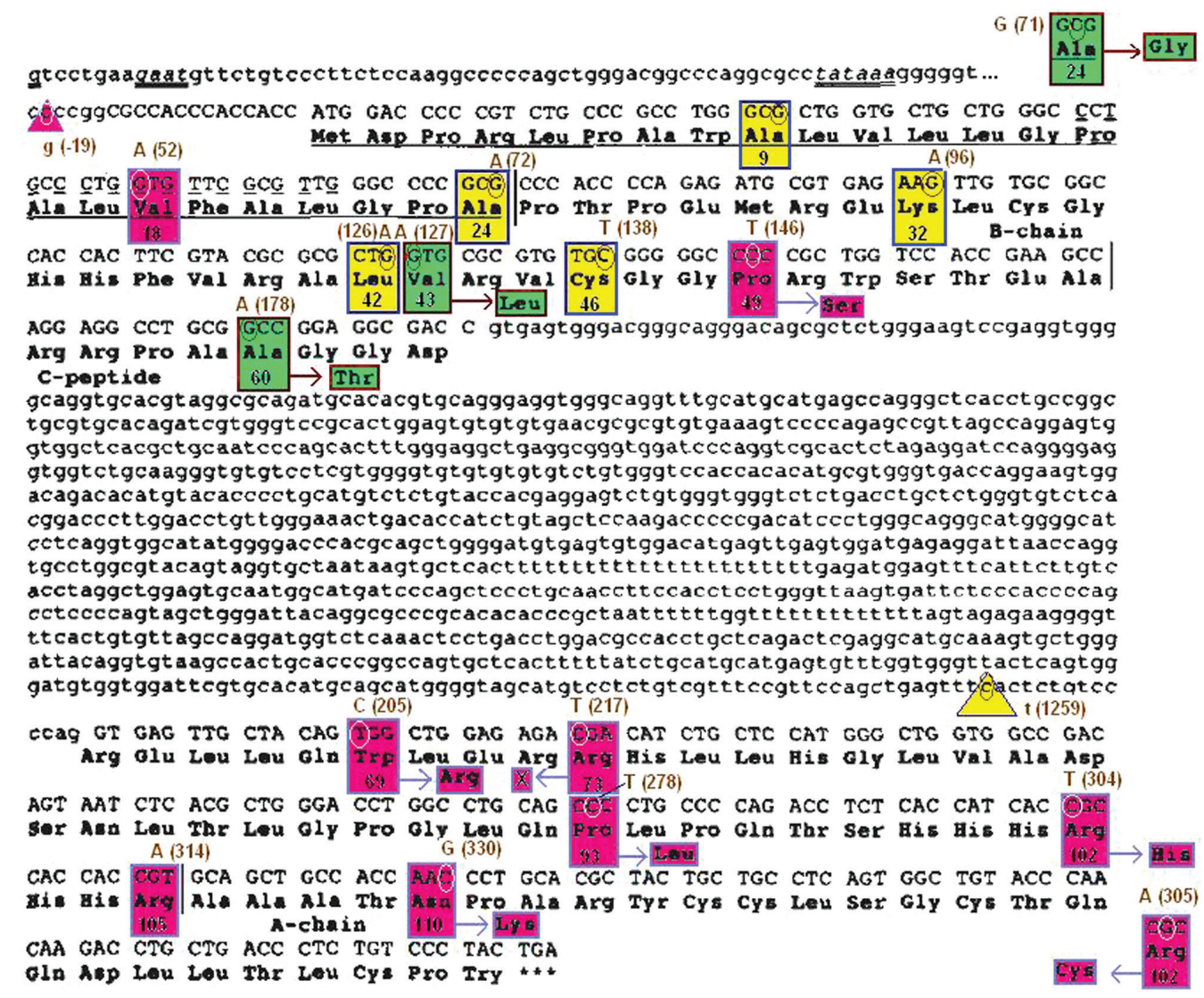

Figure 1. Nucleotide sequence of the human INSL3 gene. Exon sequences (uppercase letters), intron and $3^{\prime} / 5$ side part sequences (lowercase letters) are shown. The initial promoter sequence (200bp) is shown (lowercase letters) on top. Numbering of the amino acids follows the encoding of the respective protein. ${ }^{103} \mathrm{~B}$-chain and $\mathrm{C}$ peptide ends are indicated (vertical lines). The signal peptide is underlined. Nucleotide numbering starts from the $1^{\text {st }}$ nucleotide of the $1^{\text {st }}$ codon, which encodes the $1^{\text {st }}$ amino acid (methionine) of the pre-protein molecule (signal peptide-B-C-A). Numbering does not include intron nucleotides (modified from reference 113). The main genetic alterations reported to date are shown. Rectangulars and triangulars indicate the genetic alterations within and outside the gene coding region (promoter, intron), respectively. The synonymous single nucleotide polymorphisms (yellow), the non-synonymous single nucleotide polymorphisms (green) and the mutations are indicated (red). The type, the exact position of the nucleotide changes and the new amino acids are shown. Codons 24 and 102 are shown twice to indicate the second alteration described in them. 
Several studies in humans have investigated the possibility that genetic alterations of the INSL3 gene are implicated etiologically in TD impairment; however, most of them have failed to indicate such an association. ${ }^{8}$ An overview of the detected alterations is shown in Figure $1 .^{8,115-118}$ At least nine genetic alterations have been detected both in patients and controls (neutral synonymous single nucleotide polymorphisms ${ }^{8,115-118}$ or non-synonymous single nucleotide polymorphisms, ${ }^{8,115-118}$ isolated or in combination affecting almost exclusively exon 1). In addition, 12 mutations (genetic alterations seen exclusively in patients; missense point mutations affecting almost exclusively exon 2 and a nonsense mutation), all in the heterozygous state, have been detected. ${ }^{117,118}$ The cumulated incidence of INSL3 gene mutations in cases with TD impairment compared to normal controls is reported to be statistically significant but relatively low (1.6-2.2\%). ${ }^{119-121}$ The difference is insignificant between bilateral/unilateral cases. ${ }^{121}$ There is no definite evidence of a causal role for many of them, but they undoubtedly represent the first description of human genetic alterations related specifically to TD impairment. ${ }^{121}$

In adition, INSL3 levels have been correlated with the risk of TD impairment in humans. ${ }^{3,122}$ Presence of INSL3 in male cord blood suggests presence of the hormone along with testosterone during scrotal descent. Reduced INSL3 levels in cord blood and increased LH/INSL3 ratio at 3 months of age were detected in boys with TD impairment compared to unaffected boys. Both findings suggest a slightly impaired Leydig cell function already in early postnatal life in cases with TD impairment. However, the findings cannot establish whether reduced INSL3 levels have any causal influence on the position of the testes in the affected boys, or if reduced levels are merely a consequence of TD impairment. In any case, reduced INSL3 levels in perinatal life could reflect reduced levels during embryogenesis and a concomitant delay of the entire TD process, the result being descent of the testis postnatally or persistent TD impairment.

Investigators have also focused on the potential role of genetic alterations of the human LGR8 gene in TD impairment. The cumulative frequency of mutations is reported to be high (2.9\%) but still modest. ${ }^{123}$ Studies have mainly focused on one specific screen- ing site, namely the T222P variant located in exon 8 resulting in an A-to-C nucleotide change at position 664. ${ }^{124}$ This is a missence mutation, the only one detected to date, that was first described in a French patient (heterozygote) having both testes located in the inguinal canal on the external ring. ${ }^{124}$ According to human in vitro data, this mutation reduces LGR8 expression on the cell surface membrane, ${ }^{125}$ which may cause TD impairment. The findings are supported by some mutation screening studies in Italian men, ${ }^{125,126}$ but could not be further confirmed in other studies on Italian, ${ }^{127}$ Spanish, ${ }^{126}$ Hungarian, ${ }^{127}$ Finnish,,${ }^{128}$ Egyptian, ${ }^{127}$ Moroccan, ${ }^{129}$ American or Japanese patients, leading to the notion that mutations involving this gene do not represent a frequent cause of TD impairment and that the phenotype may be dependent on the genetic andor environmental background.

\section{Inguinoscrotal phase of TD}

\section{The role of abdominal pressure and the gubernaculum}

ISTD is currently thought to be regulated by a combination of mechanical and hormonal factors. It is hypothesized that the abdominal pressure caused by visceral growth ${ }^{52}$ combined with putative gubernacular morphological and compositional changes compose a force pushing down the testes through the inguinal canal. Conditions that result in TD impairment hypothetically associated with decreased abdominal pressure include prune-belly syndrome, cloacal exstrophy, omphalocele, gastroschisis and a number of syndromes that incorporate both TD impairment and congenital abdominal wall muscular defects/agenesis. ${ }^{130,131}$ Abdominal pressure probably has an ancillary role in TTD, playing thereafter a more significant role during ISTD. ${ }^{132}$ Androgens may also play a part at this stage of development. ${ }^{52}$ It has been experimentally demonstrated that in the presence of androgen, silicone prosthesis descends from the abdomen into the scrotum but this occurs less frequently when androgen is removed. ${ }^{52}$

The role of the gubernaculum in ISTD remains controversial. Regression of the bulky bulb, which is particularly prominent in the pig, was thought to be sufficient to allow the testis to reach the scrotum. ${ }^{44}$ A significant active migratory phase in humans ${ }^{41}$ and rodents ${ }^{133}$ has been shown, although this is disputed by 
some authors supporting the central role of involution and eversion of the gubernacular. ${ }^{42,51,134}$ Recently it has been suggested that the gubernacular bulb proliferates actively in rodents after birth and possibly differentiates into new cremaster muscle cells. ${ }^{135} \mathrm{On}$ the other hand, in the human, ${ }^{136}$ gubernacular connective tissue undergoes extensive remodelling during TD leading to final gubernacular transformation into an essentially fibrous structure rich in collagen/elastic fibers. Such changes decrease gubernacular size and thus contribute together with other forces to testis movement towards the scrotum. Active contraction of the human gubernaculum is less likely to occur due to lack of smooth muscle cells and the limited amount of striated muscle cells.

\section{ISTD is androgen-dependent}

It is generally agreed that ISTD is androgen-dependent. ${ }^{9,43,86}$ Gubernacular migration beyond the inguinal region is absent in gonadotropin-deficient animals ${ }^{137}$ as well as in both Tfm animals and humans with complete androgen resistance. ${ }^{57}$ Furthermore, about $50 \%$ of animals treated prenatally with flutamide exhibit deraranged gubernacular migration and delayed regression. ${ }^{138-142}$ Regression of the gubernacular bulb appears to be androgen-dependent since in humans with complete androgen resistance the gubernaculum remains enlarged, with failure of extracellular matrix resorption. ${ }^{91,134}$ The mechanism (direct or indirect) of androgenic action on the gubernaculum is controversial. It seems quite possible that androgens act indirectly on the gubernaculum to mediate ISTD. AR localization studies in humans have demonstrated the presence of the receptor in the cremaster muscle but not in the gubernaculum. ${ }^{143}$ However, these studies have been performed on postnatal tissues only and it is not clear whether the AR is expressed in the gubernaculum or cremaster muscle at the time of human ISTD. ARs have been detected in cultured porcine gubernacular fibroblasts ${ }^{144}$ but the total concentration and receptor binding affinity/capacity of the above ARs have been reported to be significantly lower than in recognized androgen target organs such as the prostate and urethra, comparable to that of male or feminine striated muscle. ${ }^{71,145} 5 \alpha$-reductase activity has been reported to remain constant throughout gestation in the porcine gubernaculum at levels lower than those seen in the prostate/urethra. ${ }^{146}$ The AR level of expression at the mesenchymal core of the rat gubernaculum declines during ISTD. ${ }^{71}$ The total amount of specific androgen bound in the neonatal rat gubernaculum is reported to be $20 \%$ of the amount measured in the urogenital sinus. ${ }^{147}$

\section{The GFN hypothesis}

According to this hypothesis, androgens act primarily on the GFN nuclei in the central nervous system rather than directly on the gubernaculum. As a result, the GFN releases a neurotransmitter [suggested as being the calcitonin gene-related peptide (CGRP)] that acts as a second messenger of androgenic stimulation upon the gubernaculum to mediate ISTD. ${ }^{148}$ The hypothesis, originated in 1948 by Lewis, ${ }^{149}$ who prevented TD in newborn rats by GFN transection while testing the "traction theory", supported the notion that cremaster muscle traction pulls the testis into the scrotum. ${ }^{149}$ The idea was that since the cremaster receives GFN fibers, nerve transection would paralyze the muscle thereby preventing TD. However, many workers were critical of this concept believing that cremaster contraction pulls the testis up to the groin rather down to the scrotum. Nevertheless, an intriguing finding was that denervation blocks an androgen-dependent process, leading to the speculation that androgens act prenatally via GFN. ${ }^{148}$ Indeed, AR expression has been demonstrated at the lumbar spinal cord of the rat fetus as early as at 15 days of gestation. ${ }^{150}$ Studies with antiandrogens confirm that ISTD, although occurring postnatally in rodents, can only be blocked prenatally. ${ }^{79,138,140-142}$

The GFN hypothesis is consistent with the results of distal transection of the gubernaculum in neonatal rats that prevents gubernacular postnatal migration/ ISTD, while proximal transection preserving the gubernacular nerve supply fails to block ISTD. ${ }^{151-153}$ Furthermore, this hypothesis predicts that neuronal anomalies affecting the GFN nucleus should be associated with TD impairment. This is in fact the case among children with spina bifida, particularly when the myelomeningocele is in the high lumbar region (above L4; the origin of GFN). ${ }^{154} \mathrm{~A}$ similar result can be obtained by neonatal rat spinal cord transection at the level of the low thoracic-high lumbar region, leading to TD impairment in $75 \%$ of cases. ${ }^{154}$ 
Although the role of the GFN/CGRP in TD has been well established in rodents, ${ }^{152-157}$ this is not the case in humans. ${ }^{43,62}$ CGRP acts on the muscular component of a rodent's developing gubernaculum, ${ }^{155,156}$ which is primarily cremasteric muscle. ${ }^{62}$ The human gubernaculum consists mostly of mucopolysacharides without containing almost any muscular component, a proposed target for CGRP action. ${ }^{65,136}$ However, this observation tends not to assign to CGRP a significant role in human TD. ${ }^{43,62}$ Furthermore, there is no evidence that CGRP gene mutations are involved in human TD impairment. ${ }^{158}$

The exact primary GFN target location of androgens is thus far unknown. Early studies evaluated the hypothesis that the motor GFN nucleus (L1-L2) represents the primary target organ of circulating androgens. ${ }^{56,138,146,159,160}$ This nucleus is sexually dimorphic in rodents but cell number sexual dimorphism is lost after flutamide treatment in newborn rats, despite the fact that antiandrogens cause a minor decrease in its cell content. ${ }^{159,160}$ This may be due to an increase of the number of cell bodies in females rather than to a significant loss of cell bodies in males as has been proposed. ${ }^{138}$ Furthermore, androgens have no effect on the nucleus since in rats ${ }^{106}$ and mice ${ }^{161}$ with testicular feminization, nucleus size is similar to that of normal animals, while rat GFN motoneurons lack CGRP immunoreactivity. ${ }^{162,163}$ Dense CGRP immunoreactive varicose fibres surrounding GFN motoneuron cells have been described in male but not in female rats. ${ }^{162}$

Recently it has been shown that the rat GFN sensory nucleus (L1-L2 dorsal root ganglia) is also sexually dimorphic. ${ }^{164}$ Flutamide decreases the number of cells both in male and female rats, but a significant decrease of the CGRP immunoreactive cells is detected only in males. ${ }^{164}$ Furthermore, in mutant trans-scrotal rats (TS; a natural model of TD impairment), the sensory GFN nucleus ipsilateral to the maldescended testis contains significantly more CGRP immunoreactive cells compared to the contralateral normally descended testis. ${ }^{165}$ It has been hypothesized that TD impairment in this strain may be due to a primary CGRP receptor defect and that the increased number of CGRP immunoreactive cells represents an insufficient compensatory mechanism. Based on these results, the GFN hypothesis has been modified to include a possible role of circulating androgens acting on the sensory instead of the motor GFN nucleus as previously thought. ${ }^{164}$

Finally, quite recent preliminary evidence suggests a role for the mammary line in triggering ISTD with possible trophic stimulation of the GFN to produce CGRP. ${ }^{166}$ According to this novel hypothesis, the mammary line may also be involved in the initiation of migration as follows. Testicular testosterone acts on AR in the subcutaneous mesenchyme of the mammary line, immediately superficial to the gubernaculum. Mesenchymal AR stimulation causes production of a neurotropin, which is taken up by the GFN sensory fibers and masculinizes the nerve. The GFN then produces CGRP, which is released from the sensory nerve endings with, as an overall result, the migration of the gubernaculum to the scrotum.

\section{INSL3 - testosterone interplay in TD regulation}

The widely used biphasic TD description has evolved to the belief that INSL3 and testosterone regulates TTD and ISTD, respectively. However, emerging evidence of a more complex regulation with INSL3 involvement in all aspects of gubernacular reorganization supports the idea that phasial division may be arbitrary and that the concept of distinct phasial hormonal regulation may represent an oversimplification. ${ }^{3}$ Experiments in rodents suggest high interconnectivity between INSL3, testosterone and their receptors. INSL3 receptor ablation in mice results in pronounced apoptosis of androgen-receptor-positive cells within the cranial part of the gubernaculum and diminished gubernacular swelling reaction. ${ }^{167}$ Experiments in LH-receptor-knockout mice show that testosterone treatment upregulates INSL3 receptor expression in the gubernaculum/cremaster muscle in an androgen-receptor-dependent fashion. ${ }^{168}$ Presence of both INSL3 and testosterone are necessary for reorganization of the gubernaculum, and addition of an INSL3 receptor antagonist curtails testosteroneinduced ISTD. ${ }^{168}$ In addition, testosterone has been shown to stimulate INSL3 expression in a human Leydig cell line. ${ }^{169}$ These data suggest that during TTD and ISTD, the INSL3-testosterone-receptors interplay is closer than initially supposed. The significance of this interplay in humans needs further clarification. 


\section{ACKNOWLEDGEMENTS}

Mrs D. Pantartzi, Scientific Secretary of the Clinical Trial Office at the Department of Urology, University of Crete Medical School, is gratefully acknowledged for her administrative and technical support.

\section{REFERENCES}

1. Hutson JM, Balic A, Nation T, Southwell B, 2010 Cryptorchidism. Semin Pediatr Surg 19: 215-224.

2. Toppari J, Kaleva M, 1999 Maldescendus testis. Horm Res 6: 261-291.

3. Bay K, Main KM, Toppari J, Skakkebæk NE, 2011 Testicular descent: INSL3, testosterone, genes and the intrauterine milieu. Nat Rev Urol 8: 187-196.

4. Massart F, Saggese G, 2009 Sex steroidal targets \& genetic susceptibility to idiopathic cryptorchidism. Pediatr Endocrinol Rev 6: 481-490.

5. Jensen MS, Toft G, Thulstrup AM, et al, 2010 Cryptorchidism concordance in monozygotic and dizygotic twin brothers, full brothers, and half-brothers. Fertil Steril 93: 124-129.

6. Mamoulakis C, Sofikitis N, Tsounapi P, et al, 2013 The (TAAAA)(n) polymorphism of sex hormone-binding globulin gene is not associated with testicular maldescent. Andrologia 45: 40-45.

7. Mamoulakis C, Georgiou I, Dimitriadis F, et al, 2013 Screening for $\mathrm{Y}$ chromosome microdeletions in childhood: lack of evidence for a direct association with testicular maldescent. Andrologia 45: 409-416.

8. Mamoulakis C, Georgiou I, Dimitriadis F, et al, 2014 Genetic analysis of the human Insulin-like 3 gene: absence of mutations in a Greek paediatric cohort with testicular maldescent. Andrologia 46: 986-996.

9. Hutson JM, Beasley SW 1992 Descent of the Testis. Edward Arnold, London.

10. Carrick FN, Setchell BP 1977 The evolution of the scrotum. In: Calaby JH and Tyndale-Biscoe T (eds) Reproduction and evolution. Australian Academy of Science, Camberra; pp, 165-170.

11. Harrison RM, Lewis RW 1986 The male reproductive tract and its fluids. In: Dukelow WR, Ervin J (eds) Comparative Primate Biology. Alan R Liss, New York; pp, 101-148.

12. Kinzey WG 1971 Male reproductive system and spermatogenesis. In: Hafez ESE, Springfield IL, Charles C (eds), Comparative Reproduction of Nonhuman Primates. McGraw-Hill Company of Canada, Scarborough, Ontario; pp, 85-114.

13. Moore KL, Persaud TV 1993 Clinically oriented Embryology. WB Saunders Co, Philadelphia.

14. Moore CR, 1926 The biology of the mammalian testis and scrotum. Q Rev Biol 1: 4-50.

15. Short RV, 1997 The testis: the witness of the mating system, the site of mutation and the engine of desire. Acta Paediatr Suppl 422: 3-7.

16. Portman A 1952 Animal forms and Patterns. Schocken, New York.

17. Bedford JM, 1978 Anatomical evidence for the epididymis as the prime mover in the evolution of the scrotum. Am J Anat 152: 483-507.

18. Freeman S, 1990 The evolution of the scrotum: a new hypothesis. J Theor Biol 145: 429-445.

19. Setchell BP, 1998 The Parkes Lecture. Heat and the testis. J Reprod Fertil 114: 179-194.

20. Cowles RB, 1965 Hyperthermia, aspermia, mutation rates and evolution. Q Rev Biol 40: 728 341-367.

21. VanDemark NL, Free MJ 1970 Temperature effects. In: Johnson AD, Gomes WR, VanDemark NL (eds), The Testis. Academic Press, New York; pp, 233-312.

22. Waites GM 1970 Temperature regulation and the testis. In: Johnson AD, Gomes WR, VanDemark NL (eds) The Testis. Academic Press, New York; pp, 241-279.

23. Blix AS, Fay FH, Ronald K, 1983 On testicular cooling in phocid seals. Polar Res 1: 231-233.

24. Pabst DA, Rommel SA, McLellan WA, Williams TM, Rowles TK, 1995 Thermoregulation of the intra-abdominal testes of the bottlenose dolphin (Tursiops truncatus) during exercise. J Exp Biol 198: 221-226.

25. Macdonald D 1984 The encyclopedia of mammals. Unwin Hynam, London, UK.

26. Hanks J 1977 Comparative aspects of reproduction in the male hyrax and elephant. In Calaby JG, TyndaleBiscoe HD (eds) Reproduction and evolution. Australian Academy of Sience, Cambera, Australia, pp, 155-164.

27. Shimmin LC, Chang BH and Li WH, 1993 Male-driven evolution of DNA sequences. Nature 362: 745-747.

28. Shimmin LC, Chang BH, Li WH, 1994 Contrasting rates of nucleotide substitution in the X-linked and Y-linked zinc finger genes. J Mol Evol 39: 569-578.

29. Ehrenberg L, Ehrenstein GV, Hedgran A, 1957 Gonadal temperatures and spontaneous mutation rates in man. Nature 180: 1433-1434.

30. Wolfson A, 1954 Sperm storage at lower-than-body temperature outside the body cavity of some passerine birds. Science 120: 68-71.

31. Woodal PF, 1995 The male reproductive system and the phylogeny of elephant-shrews. Mammal Rev 25: 87-93.

32. Waites GM, Sethell BP 1969 Some physiological aspects of the function of the testis. In Meckerns KW (ed), The gonads. Appleton-Century-Crofts, New York; pp, 649-714.

33. Eckert R, Randall D 1983 Animal physiology. Freeman, New York.

34. Ginsberg JR, Huck UW, 1989 Sperm competition in mammals. Trends Ecol Evol 4: 74-79.

35. Hunter J 1786 A description of the situation of the testis in the foetus, with its descent into the scrotum. In Observations on certain parts of the animal oeconomy. London, 13 Castle St, pp, 1-26. 
36. Williams MP, Hutson JM, 1991 The history of ideas about testicular descent. Pediatr Surg Int 6: 180-184.

37. Cleland J 1856 The mechanism of the gubernaculum testis, with an introductory sketch of the development of the testes, and an appendix on the purpose of their descent from the abdomen. Edinburgh, Maclachan and Stewart.

38. Gier HT, Marion GB, 1969 Development of mammalian testes and genital ducts. Biol Reprod 1(Suppl): 1-23.

39. Hutson JM, 1985 A biphasic model for the hormonal control of testicular descent. Lancet 2: 419-421.

40. Backhouse KM, 1982. Embryology of testicular descent and maldescent. Urol Clin North Am 9: 315-325.

41. Heyns CF, 1987 The gubernaculum during testicular descent in the human fetus. J Anat 153: 93-112.

42. Hadziselimovic F, Herzog B, Kruslin E, 1979 Morphological background of estrogen-induced cryptorchidism in the mouse. Pediatr Adolesc Endocrinol 6: 79-87.

43. Hutson JM, Hasthorpe S, Heyns CF, 1997 Anatomical and functional aspects of testicular descent and cryptorchidism. Endocr Rev 18: 259-280.

44. Wensing CJ, 1973 Testicular descent in some domestic mammals 2 . The nature of the gubernacular change during the process of testicular descent in the pig. Proc K Ned Akad Wet C 76: 190-195.

45. Hadziselimovic F, Herzog B, Kruslin E, 1980 Estrogen induced cryptorchidism in animals. Clin Androl 3: $166-174$.

46. van der Schoot P, 1993 Doubts about the 'first phase of testis descent' in the rat as a valid concept. Anat Embryol (Berl) 187: 203-208.

47. Clarnette TD, Hutson JM, Beasley SW, 1996 Factors affecting the development of the processus vaginalis in the rat. J Urol 156: 1463-1466.

48. Wensing CJ, Colenbrander B, van Straaten HW 1980 Normal and abnormal testicular descent in some mammals. In ESE Hafez (ed) Clinics in Andrology: Descended and Cryptorchid Testis. Martinus Nijhoff, The Hague; pp, 125-137.

49. Tayakkanonta K, 1963 The gubernaculum testis and its nerve supply. Aust NZ J Surg 33: 61-67.

50. Heyns CF, 1982 The gubernaculum during testicular descent and maldescent. Urol Clin N Am 9: 315-325.

51. Elder JS, Isaacs JT, Walsh PC, 1982 Androgenic sensitivity of the gubernaculum testis: evidence for hormonal/ mechanical interactions in testicular descent. J Urol 127: $170-176$.

52. Frey HL, Peng S, Rajfer J, 1983 Synergy of abdominal pressure and androgens in testicular descent. Biol Reprod 29: 1233-1239.

53. Hutson JM, Terada M, Zhou B, Williams MP, 1995 Normal testicular descent and the aetiology of cryptorchidism. Adv Anat Embryol Cell Biol 132: 1-56.

54. Kersten W, Molenaar GJ, Emmen JM, van der Schoot P, 1996 Bilateral cryptorchidism in a dog with persistent cranial testis suspensory ligaments and inverted gubernacula: report of a case with implications for understanding normal and aberrant testis descent. J Anat 189: 171-176.

55. van der Schoot P, Emmen JM, 1996 Development, structure and function of the cranial suspensory ligaments of the mammalian gonads in a cross-species perspective; their possible role in effecting disturbed testicular descent. Hum Reprod Update 2: 399-418.

56. Barthold JS, Mahler HR, Newton BW, 1994 Lack of feminization of the cremaster nucleus in cryptorchid androgen insensitive rats. J Urol 152: 2280-2286.

57. van der Schoot P, Elger W, 1992 Androgen-induced prevention of the outgrowth of cranial gonadal suspensory ligaments in fetal rats. J Androl 13: 534-542.

58. Clarnette TD, Sugita Y, Hutson JM, 1997 Genital anomalies in human and animal models reveal the mechanisms and hormones governing testicular descent. Br J Urol 79: 99-112.

59. Hutson JM, 1986 Testicular feminization: a model for testicular descent in mice and men. J Pediatr Surg 21: 195-198.

60. Emmen JM, McLuskey A, Grootegoed JA, Brinkmann AO, 1998 Androgen action during male sex differentiation includes suppression of cranial suspensory ligament development. Hum Reprod 13: 1272-1280.

61. Scott JE, 1987 The Hutson hypothesis. A clinical study. Br J Urol 60: 74-76.

62. Husmann DA, Levy JB, 1995 Current concepts in the pathophysiology of testicular undescent. Urology 46: 267-276.

63. Backhouse KM, Butler H, 1960 The gubernaculum testis of the pig (sus scropha). J Anat 94: 107-121.

64. Heyns CF, Human HJ, DeKlerk DP, 1986 Hyperplasia and hypertrophy of the gubernaculum during testicular descent in the fetus. J Urol 135: 1043-1047.

65. Heyns CF, Human HJ, Werely CJ, De Klerk DP, 1990 The glycosaminoglycans of the gubernaculum during testicular descent in the fetus. J Urol 143: 612-617.

66. Lillie FR, 1917 The freemartin: a study of the action of sex hormones in the foetal life of a cattle. J Exp Zool 23: 371-452.

67. Van der Schoot P, Vigier B, Prepin J, Perchellet JP, Gittenberger de Groot A, 1995 Development of the gubernaculum and processus vaginalis in freemartinism: further evidence in support of a specific fetal testis hormone governing male-specific gubernacular development. Anat Rec 241: 211-224.

68. van der Schoot P, 1993 Foetal testes control the prenatal growth and differentiation of the gubernacular cones in rabbits-a tribute to the late Professor Alfred Jost. Development 118: 1327-1334.

69. Habenicht UF, Neumann F, 1983 Hormonal regulation of testicular descent. Adv Anat Embryol Cell Biol 81: 1-54.

70. Bentvelsen FM, George FW, 1993 The fetal rat gubernaculum contains higher levels of androgen receptor than does the postnatal gubernaculum. J Urol 150: 
1564-1566

71. Husmann DA, McPhaul MJ, 1991 Localization of the androgen receptor in the developing rat gubernaculum. Endocrinology 128: 383-387.

72. Heyns CF, Pape VC, 1991 Presence of a low capacity androgen receptor in the gubernaculum of the pig fetus. J Urol 145: 161-167.

73. Ahmed SF, Cheng A, Dovey L, et al, 2000 Phenotypic features, androgen receptor binding, and mutational analysis in 278 clinical cases reported as androgen insensitivity syndrome. J Clin Endocrinol Metab 85: 658-665.

74. Fentener van Vlissingen JM, Colenbrader B, Verbruggen A, Wensing CJ 1984 Testicular feminized males (TFM) in Nyctereutes procyonoides (Raccoon, dog). In Recent Progress in Cellular Endocrinology of the Testis. INSERM Symposium, Elsevier, Amsterdam; pp, 335-340.

75. Wensing CJ, Colenbrander B, Bosma AA, 1975 Testicular feminisation syndrome and gubernacular development in a pig. Proc K Ned Akad Wet C 78: 402-405.

76. Elger W, Richter J, Korte R 1977 Failure to detect androgen dependence of the descensus testiculorum in foetal rabbits, mice and monkeys. In: Bierich JR, Rager K, Ranke MB (eds) Maldescensus testis. Urban \& Schwarzenberg, Baltimore; pp, 187-191.

77. Hutson JM, Beasley SW, 1988 Embryological controversies in testicular descent. Semin Urol 6: 68-73.

78. Wensing CJ, 1973 Testicular descent in some domestic mammals. 3. Search for the factors that regulate the gubernacular reaction. Proc K Ned Akad Wet C 76: 196-202.

79. Shono T, Ramm Anderson S, Goh DW, Hutson JM, 1994 The effect of flutamide on testicular descent in rats examined by scanning electron microscopy. J Pediatr Surg 29: 839-844.

80. Baumans V, Dijkstra G, Wensing CJ, 1982 The effect of orchidectomy on gubernacular outgrowth and regression in the dog. Int $\mathrm{J}$ Androl 5: 387-400.

81. Baumans V, Dijkstra G, Wensing CJ, 1983 The role of a non-androgenic testicular factor in the process of testicular descent in the dog. Int J Androl 6: 541-552.

82. Emmen JM, McLuskey A, Adham IM, Engel W, Grootegoed JA, Brinkmann AO, 2000 Hormonal control of gubernaculum development during testis descent: gubernaculum outgrowth in vitro requires both insulin-like factor and androgen. Endocrinology 141: 4720-4727.

83. Fentener van Vlissingen JM, van Zoelen EJ, Ursem PJ, Wensing CJ, 1988 In vitro model of the first phase of testicular descent: identification of a low molecular weight factor from fetal testis involved in proliferation of gubernaculum testis cells and distinct from specified polypeptide growth factors and fetal gonadal hormones. Endocrinology 123: 2868-2877.

84. Kubota Y, Temelcos C, Bathgate RA, et al, 2002 The role of insulin 3, testosterone, Mullerian inhibiting substance and relaxin in rat gubernacular growth. Mol Hum Reprod 8: 900-905.

85. Visser JH, Heyns CF, 1995 Proliferation of gubernaculum cells induced by a substance of low molecular mass obtained from fetal pig testes. J Urol 153: 516-520.

86. Hadziselimovic F 1983 Embryology of Testicular Descent and Maldescent. In: Hadziselimovic F (ed) Cryptorchidism. Management and Implications. Springer-Verlag, Berlin; pp, 11-34.

87. Raynaud A, 1958 Inhibition, sous l'effect d'une hormone oestrogène, du développement du gubernaculum du fœtus mâle de souris. CR Acad Sc Paris 246: 176-179.

88. Shono T, Hutson JM, Watts L, et al, 1996 Scanning electron microscopy shows inhibited gubernacular development in relation to undescended testes in oestrogentreated mice. Int J Androl 19: 263-270.

89. Hutson JM, 1987 Exogenous oestrogens prevent transabdominal testicular descent in mice with complete androgen resistance (testicular feminization). Pediatr Surg Int 2: 242-246.

90. Hutson JM, Watts LM, 1990 Both gonadotropin and testosterone fail to reverse estrogen-induced cryptorchidism in fetal mice: further evidence for nonandrogenic control of testicular descent in the fetus. Pediatr Surg Int 5: 13-18.

91. Hutson JM, Donahoe PK, 1986 The hormonal control of testicular descent. Endocr Rev 7: 270-283.

92. Hutson JM, Chow DW, Ng WD, 1987 Persistent Mullerian duct syndrome with transverse testicular ectopia. An experiment of the nature with clues for understanding testicular descent. Pediatr Surg Int 2: 191-194.

93. Hutson JM, Davidson PM, Reece LA, Baker M, Zhou B, 1994 Failure of gubernacular development in the persistent Müllerian duct syndrome allows herniation of the testes. Pediatr Surg Int 9: 544-546.

94. Tran D, Picard JY, Vigier B, Berger R, Josso N, 1986 Persistence of mullerian ducts in male rabbits passively immunized against bovine anti-mullerian hormone during fetal life. Dev Biol 116: 160-167.

95. Bartlett JE, Lee SM, Mishina Y, et al, 2002 Gubernacular development in Mullerian inhibiting substance receptordeficient mice. BJU Int 89; 113-118.

96. Behringer RR, Finegold MJ, Cate RL, 1994 Mullerianinhibiting substance function during mammalian sexual development. Cell 79: 415-425.

97. Mishina Y, Rey R, Finegold MJ, et al, 1996 Genetic analysis of the Mullerian-inhibiting substance signal transduction pathway in mammalian sexual differentiation. Genes Dev 10: 2577-2587.

98. Catlin EA, MacLaughlin DT, Donahoe PK, 1993 Mullerian inhibiting substance: new perspectives and future directions. Microsc Res Tech 25: 121-133.

99. Guerrier D, Tran D, Vanderwinden JM, et al, 1989 The persistent Mullerian duct syndrome: a molecular approach. J Clin Endocrinol Metab 68: 46-52. 
100. Josso N, Picard JY, Imbeaud S, di Clemente N, Rey R, 1997 Clinical aspects and molecular genetics of the persistent mullerian duct syndrome. Clin Endocrinol (Oxf) 47: 137-144.

101. Nef S, Parada LF, 1999 Cryptorchidism in mice mutant for Insl3. Nat Genet 22: 295-299.

102. Zimmermann S, Steding G, Emmen JM, et al, 1999 Targeted disruption of the Insl3 gene causes bilateral cryptorchidism. Mol Endocrinol 13: 681-691.

103. Adham IM, Burkhardt E, Benahmed M, Engel W, 1993 Cloning of a cDNA for a novel insulin-like peptide of the testicular Leydig cells. J Biol Chem 268: 26668-26672.

104. Zimmermann S, Schottler P, Engel W, Adham IM, 1997 Mouse Leydig insulin-like (Ley I-L) gene: structure and expression during testis and ovary development. Mol Reprod Dev 47: 30-38.

105. Ivell R, Balvers M, Domagalski R, Ungefroren H, Hunt N, Schulze W, 1997 Relaxin-like factor: a highly specific and constitutive new marker for Leydig cells in the human testis. Mol Hum Reprod 3: 459-466.

106. Adham IM, Emmen JM, Engel W, 2000 The role of the testicular factor INSL3 in establishing the gonadal position. Mol Cell Endocrinol 160: 11-16.

107. Irving Rodgers HF, Bathgate RA, Ivell R, Domagalski $\mathrm{R}$, Rodgers RJ, 2002 Dynamic changes in the expression of relaxin-like factor (INSL3), cholesterol side-chain cleavage cytochrome p450, and 3beta-hydroxysteroid dehydrogenase in bovine ovarian follicles during growth and atresia. Biol Reprod 66: 934-943.

108. Kubota Y, Nef S, Farmer PJ, Temelcos C, Parada LF, Hutson JM, 2001 Leydig insulin-like hormone, gubernacular development and testicular descent. J Urol 165: 1673-1675.

109. Nguyen MT, Showalter PR, Timmons CF, Nef S, Parada LF, Baker LA, 2002 Effects of orchiopexy on congenitally cryptorchid insulin-3 knockout mice. J Urol 168: 1779-1783.

110. Adham IM, Steding G, Thamm T, et al, 2002 The overexpression of the ins13 in female mice causes descent of the ovaries. Mol Endocrinol 16: 244-252.

111. Kumagai J, Hsu SY, Matsumi H, et al, 2002 INSL3/ Leydig insulin-like peptide activates the LGR8 receptor important in testis descent. J Biol Chem 277: 31283-31286.

112. Kawamura K, Kumagai J, Sudo S, et al, 2004 Paracrine regulation of mammalian oocyte maturation and male germ cell survival. Proc Natl Acad Sci USA 101: 7323-7328.

113. Burkhardt E, Adham IM, Brosig B, Gastmann A, Mattei MG, Engel W, 1994 Structural organization of the porcine and human genes coding for a Leydig cell-specific insulin-like peptide (LEY I-L) and chromosomal localization of the human gene (INSL3). Genomics 20: 13-19.

114. Donaldson KM, Tong SY, Washburn T, et al, 1996
Morphometric study of the gubernaculum in male estrogen receptor mutant mice. J Androl 17: 91-95.

115. Koskimies P, Virtanen H, Lindström M, et al, 2000 A common polymorphism in the human relaxin-like factor (RLF) gene: no relationship with cryptorchidism. Pediatr Res 47: 538-541.

116. Krausz C, Quintana-Murci L, Fellous M, et al, 2000 Absence of mutations involving the INSL3 gene in human idiopathic cryptorchidism. Mol Hum Reprod 6: 298-302.

117. Tomboc M, Lee PA, Mitwally MF, et al, 2000 Insulinlike 3/relaxin-like factor gene mutations are associated with cryptorchidism. J Clin Endocrinol Metab 85: 4013-4018.

118. Lim HN, Raipert-de Meyts E, Skakkebaek NE, et al, 2001 Genetic analysis of the INSL3 gene in patients with maldescent of the testis. Eur J Endocrinol 144: 129-137.

119. Ferlin A, Arredi B, Foresta C, 2006 Genetic causes of male infertility. Reprod Toxicol 22: 133-141.

120. Ferlin A, Arredi B, Zuccarello D, Garolla A, Selice R, Foresta C, 2006 Paracrine and endocrine roles of insulin-like factor 3. J Endocrinol Invest 29: 657-664.

121. Ferlin A, Bogatcheva NV, Gianesello L, et al, 2006 Insulin-like factor 3 gene mutations in testicular dysgenesis syndrome: clinical and functional characterization. Mol Hum Reprod 12: 401-406.

122. Bay K, Virtanen HE, Hartung S, et al, 2007 Insulin-like factor 3 levels in cord blood and serum from children: effects of age, postnatal hypothalamic-pituitary-gonadal axis activation, and cryptorchidism. J Clin Endocrinol Metab 92: 4020-4027.

123. Foresta C, Zuccarello D, Garolla A, Ferlin A, 2008 Role of hormones, genes, and environment in human cryptorchidism. Endocr Rev 29: 560-580.

124. Gorlov IP, Kamat A, Bogatcheva NV, Jones E, Lamb DJ, Truong A, et al, 2002 Mutations of the GREAT gene cause cryptorchidism. Hum Mol Genet 11: 2309-2318.

125. Bogatcheva NV, Ferlin A, Feng S, et al, 2007 T222P mutation of the insulin-like 3 hormone receptor LGR 8 is associated with testicular maldescent and hinders receptor expression on the cell surface membrane. Am J Physiol Endocrinol Metab 292: E138-144.

126. Ars E, Lo Giacco D, Bassas L, et al, 2011 Further insights into the role of T222P variant of RXFP2 in non-syndromic cryptorchidism in two Mediterranean populations. Int J Androl 34: 333-338.

127. Nuti F, Marinari E, Erdei E, et al, 2008 The leucinerich repeat-containing $\mathrm{G}$ protein-coupled receptor 8 gene T222P mutation does not cause cryptorchidism. J Clin Endocrinol Metab 93: 1072-1076.

128. Roh J, Virtanen H, Kumagai J, et al, 2003 Lack of LGR8 gene mutation in Finnish patients with a family history of cryptorchidism. Reprod Biomed Online 2003 7: 400-406.

129. El Houate B, Rouba H, Imken L, et al, 2008 No associa- 
tion between T222P/LGR8 mutation and cryptorchidism in the Moroccan population. Horm Res 70: 236-239.

130. Kaplan LM, Koyle MA, Kaplan GW, Farrer JH, Rajfer J, 1986 Association between abdominal wall defects and cryptorchidism. J Urol 136: 645-647.

131. Koivusalo A, Taskinen S, Rintala RJ, 1998 Cryptorchidism in boys with congenital abdominal wall defects. Pediatr Surg Int 13: 143-145.

132. Attah AA, Hutson JM, 1993 The role of intra-abdominal pressure in cryptorchidism. J Urol 150: 994-996.

133. Fallat ME, Williams MPL, Farmer PJ, Hutson JM, 1992 Histologic evaluation of inguinoscrotal migration of the gubernaculum in rodents during testicular descent and its relationship to the genitofemoral nerve. Pediatr Surg Int 7: 265-270.

134. Radhakrishnan J, Donahoe PK 1981 The Gubernaculum and Testicular Descent. In: Fonkalsrud EW, Mengel W (eds) The Undescended Testis. Year Book Medical Publishers, Chicago; pp, 30-41.

135. Hrabovszky Z, Di Pilla N, Yap T, Farmer PJ, Hutson JM Carlin JB, 2002 Role of the gubernacular bulb in cremaster muscle development of the rat. Anat Rec 267: 159-165.

136. Costa WS, Sampaio FJ, Favorito LA, Cardoso LE, 2002 Testicular migration: remodeling of connective tissue and muscle cells in human gubernaculum testis. J Urol 167: 2171-2176.

137. Grocock CA, Charlton HM, Pike MC, 1988 Role of the fetal pituitary in cryptorchidism induced by exogenous maternal oestrogen during pregnancy in mice. J Reprod Fertil 83: 295-300.

138. Goh DW, Middlesworth W, Farmer PJ, Hutson JM, 1994 Prenatal androgen blockade with flutamide inhibits masculinization of the genitofemoral nerve and testicular descent. J Pediatr Surg 29: 836-838.

139. McMahon DR, Kramer SA, Husmann DA, 1995 Antiandrogen induced cryptorchidism in the pig is associated with failed gubernacular regression and epididymal malformations. J Urol 154: 553-557.

140. Spencer JR, Torrado T, Sanchez RS, Vaughan ED, Imperato McGinley J, 1991 Effects of flutamide and finasteride on rat testicular descent. Endocrinology 129: 741-748

141. Husmann DA, McPhaul MJ, 1991 Time-specific androgen blockade with flutamide inhibits testicular descent in the rat. Endocrinology 129: 1409-1416.

142. Husmann DA, McPhaul MJ, 1992 Reversal of flutamide-induced cryptorchidism by prenatal timespecific androgens. Endocrinology 131: 1711-1715.

143. Johansen TE, Klein H, 1993 Evidence of androgen receptivity in the pathway of testicular descent in humans. A postnatal study. Eur Urol 23: 466-468.

144. Oprins AC, Fentener van Vlissingen JM, Blankenstein MA, 1988 Testicular descent: androgen receptors in cultured porcine gubernaculum cells. J Steroid Biochem 31: 387-391.
145. Heyns CF, Pape VC, DeKlerk DP, 1988 Demonstration of a cytosolic androgen receptor in the gubernaculum of the pig fetus. J Urol 139: 236.

146. Heyns CF, Tate R, Sargent NS, Habib FK, Chisholm GD, 1993 Absence of 5 alpha-reductase activity in the gubernaculum during descent of the fetal pig testis. J Urol 150: 510-513.

147. George FW, Peterson KG, 1988 Partial characterization of the androgen receptor of the newborn rat gubernaculum. Biol Reprod 39: 536-539.

148. Hutson JM, Beasley SW, 1987 The mechanisms of testicular descent. Aust Paediatr J 23: 215-216.

149. Lewis LG, 1948. Cryptorchidism. J Urol 60: 345-346.

150. Cain MP, Kramer SA, Tindall DJ, Husmann DA, 1994 Expression of androgen receptor protein within the lumbar spinal cord during ontologic development and following antiandrogen induced cryptorchidism. J Urol 152: 766-769.

151. Larkins SL, Hutson JM, 1991 Fluorescent anterograde labelling of the genitofemoral nerve shows that it supplies the scrotal region before migration of the gubernaculum. Pediatr Surg Int 6: 167-171.

152. Beasley SW, Hutson JM, 1988 The role of the gubernaculum in testicular descent. J Urol 140: 1191-1193.

153. Bergh A, Helander HF, Wahlquist L, 1978 Studies on factors governing testicular descent in the ratparticularly the role of gubernaculum testis. Int $\mathbf{J}$ Androl 1: 342-356.

154. Hutson JM, Beasley SW, Bryan AD, 1988 Cryptorchidism in spina bifida and spinal cord transection: a clue to the mechanism of transinguinal descent of the testis. J Pediatr Surg 23: 275-277.

155. Park WH, Hutson JM, 1991 The gubernaculum shows rhythmic contractility and active movement during testicular descent. J Pediatr Surg 26: 615-617.

156. Momose Y, Griffiths AL, Hutson JM, 1992 Testicular descent. III. The neonatal mouse gubernaculum shows rhythmic contraction in organ culture in response to calcitonin gene-related peptide. Endocrinology 131: 2881-2884.

157. Beasley SW, Hutson JM, 1987 Effect of division of the genitofemoral nerve on testicular descent in the rat. Aust NZJ Surg 57: 49-51.

158. Zuccarello D, Morini E, Douzgou S, et al, 2004 Preliminary data suggest that mutations in the CgRP pathway are not involved in human sporadic cryptorchidism. J Endocrinol Invest 27: 760-764.

159. Barthold JS, Mahler HR, Sziszak TJ, Newton BW, 1996 Lack of feminization of the cremaster nucleus by prenatal flutamide administration in the rat and pig. J Urol 156: 767-771.

160. Goh DW, Farmer PJ, Hutson JM, 1994 Absence of normal sexual dimorphism of the genitofemoral nerve spinal nucleus in the mutant cryptorchid (TS) rat. J Reprod Fertil 102: 195-199.

161. Larkins SL, Williams MPL, Hutson JM, 1991 Local- 
ization of calcitonin gene-related peptide within the spinal nucleus of the genitofemoral nerve. Pediatr Surg Int 6: 176-179.

162. Newton BW, Unger J, Hamill RW, 1990 Calcitonin gene-related peptide and somatostatin immunoreactivities in the rat lumbar spinal cord: sexually dimorphic aspects. Neuroscience 37: 471-489.

163. Schwindt B, Farmer PJ, Watts LM, Hrabovszky Z, Hutson JM, 1999 Localization of calcitonin gene-related peptide within the genitofemoral nerve in immature rats. J Pediatr Surg 34: 986-991.

164. Hrabovszky Z, Farmer PJ, Hutson JM, 2000 Does the sensory nucleus of the genitofemoral nerve have a role in testicular descent? J Pediatr Surg 35: 96-100.

165. Hrabovszky Z, Farmer PJ, Hutson JM, 2001 Undescended testis is accompanied by calcitonin gene related peptide accumulation within the sensory nucleus of the genitofemoral nerve in trans-scrotal rats. J Urol 165: 1015-1018.

166. Hutson JM, Southwell BR, Li R, et al 2013, The regulation of testicular descent and the effects of cryptorchidism. Endocr Rev 34: 725-752.

167. Kaftanovskaya EM, Feng S, Huang Z, et al, 2011 Suppression of insulin-like 3 receptor reveals the role of $\beta$-catenin and Notch signaling in gubernaculum development. Mol Endocrinol 25: 170-183.

168. Yuan FP, Li X, Lin J, et al, 2010 The role of RXFP2 in mediating androgen-induced inguinoscrotal testis descent in LH receptor knockout mice. Reproduction 139: 759-769.

169. Laguë E, Tremblay JJ 2008 Antagonistic effects of testosterone and the endocrine disruptor mono-(2ethylhexyl) phthalate on INSL3 transcription in Leydig cells. Endocrinology 149: 4688-4694. 